TEIXEIRA, AG; CABRAL, MO; OLIVEIRA, FL; DALVI, LP; MENINI, LF; ROCHA, L. 2021. Interference of weeds on Barbados gooseberry initial development. Horticultura Brasileira 39: 155-160. DOI: http://dx.doi.org/10.1590/s0102-0536-20210205

\title{
Interference of weeds on Barbados gooseberry initial development
}

\author{
Ariany G Teixeira ${ }^{1} \mathbb{D}$; Mateus O Cabral ${ }^{1} \mathbb{D}$; Fábio Luiz de Oliveira ${ }^{1} \mathbb{D}$; Leandro P Dalvi ${ }^{1} \mathbb{D}$; Luciano \\ Menini ${ }^{2} \mathbb{D}$; Leonardo F Rocha ${ }^{3 \mathbb{D}}$
}

${ }^{1}$ Universidade Federal do Espírito Santo (UFES), Alegre-ES, Brasil; arianyteixeira@yahoo.com.br; mateus.cabrall@hotmail.com; fabio. oliveira.2@ufes.br; leandropin@yahoo.com.br; ${ }^{2}$ Instituto Federal do Espírito Santo (IFES), Alegre-ES, Brasil; 1menini@ifes.edu.br; ${ }^{3}$ School of Agricultural Sciences, Southern Illinois University, Carbondale, Illinois, USA; leonardo.rocha@siu.edu

\begin{abstract}
The Barbados gooseberry crop has agricultural potential, but little information is available regarding cropping practices. More information on weed interference in Barbados gooseberry will support growers to take weed management decisions. The objective of this work was to study initial growth and development of Barbados gooseberry under the interference of weeds. The experiment was conducted in a completely randomized design, with five treatments, composed of Barbados gooseberry in competition with four weed species: slender amaranth (Amaranthus viridis), hairy beggarticks (Bidens pilosa), Benghal dayflower (Commelina benghalensis), purple nutsedge (Cyperus rotundus), and a weed-free control, with six replicates. Weed competition led to a decrease in growth and development of Barbados gooseberry reflected in a reduction of up to $40 \%$ in yield and $23 \%$ in protein content. Additional work must be conducted evaluating these findings under field conditions, using different seedling production and planting techniques potentially affecting these results.
\end{abstract}

Keywords: Pereskia aculeata, non-conventional vegetable, competition, proteins.

\section{RESUMO}

Interferência de plantas daninhas no desenvolvimento inicial do ora-pro-nobis

Atualmente o ora-pro-nobis é apontando como cultura de potencial agrícola, porém com poucas informações sobre seu manejo agronômico. Uma das informações a ser buscada é quanto aos prejuízos que o convívio com plantas daninhas causa. Objetivou-se com este trabalho estudar o crescimento e desenvolvimento inicial do ora-pro-nobis em convivência com plantas daninhas. O delineamento experimental utilizado foi inteiramente casualizado, com cinco tratamento, ora-pro-nobis em convivência com caruru (Amaranthus viridis), picão preto (Bidens pilosa), trapoeraba (Commelina benghalensis) e tiririca (Cyperus rotundus) e a testemunha ausente de plantas daninhas, com seis repetições. A convivência com as plantas daninhas diminuiu o crescimento e desenvolvimento do orapro-nobis assim como a produção de folhas em até $40 \%$ e $23 \%$ do teor de proteínas, respectivamente. Porém, novos trabalhos devem ser realizados em ambientes de plantio a céu aberto, bem como a utilização de técnicas diferenciadas para a produção de mudas e seu transplante para as condições reais de campo.

Palavras-chave: Pereskia aculeata, hortaliça não convencional, competição, proteínas.

Received on August 7, 2020; accepted on April 12, 2021

$\mathrm{T}$ he Barbados gooseberry plant (Pereskia aculeata), included in the Cactaceae family, is native to South America and well adapted to low elevations. In Brazil, this crop is widely distributed, from Bahia to Rio Grande do Sul state (Pinto et al., 2015). This plant is a climbing cactus and conducted as a vine. Its succulent leaves are a substantial source of protein and have a significant concentration of minerals, dietary fibers, vitamins $\mathrm{A}$ and $\mathrm{C}$, and folic acid (Souza et al., 2016). Barbados gooseberry leaves are added to salads, soups, omelets, and pies, while the leaf flour is used as a nutritional enriching ingredient when preparing bread, cakes, and pasta. The fruits are used for juices, jellies, mousses, and liqueurs, whereas their seeds can be germinated to produce edible sprouts (Garcia et al., 2019).

In Brazil, this plant is commonly referred to as "green meat" or "vegetable meat" because of its high protein and mineral content. Barbados gooseberry has traditional cultural relevance in some regions of Minas Gerais and Goiás states, especially in historic colonial cities. In Diamantina city, Minas Gerais, for example, nearly $80 \%$ of the population consumes this vegetable regularly, being less common in other parts of Brazil (Garcia et al., 2019). Despite the restriction of
Barbados gooseberry consumption to specific regions, the adaptability of this plant to different environments, high production of leaf biomass, and data showing the nutritional significance of leaves have been stimulating the use of this plant in other areas. Moreover, added demand for Barbados gooseberry by the food industry highlights the agricultural potential of this plant (Queiroz et al., 2015a; Madeira et al., 2016) and demanding improved crop management practices.

As this plant is adapted to large scale production systems, management practices must be optimized to achieve higher yields, including optimized 
weed management methods, as weeds are a major biotic factor interfering with plant growth and development, and therefore reducing yield. When not properly managed, weeds can interfere with plant growth mainly by competing for resources such as water, light, and nutrients, and potentially releasing allelopathic substances, reducing yield and quality of crops (Demétrio et al., 2008; Galon et al., 2013).

Weed species are characterized by having competitive features, such as producing a high number of viable seeds, easily adapting to new environments, which facilitates plant dispersion. Furthermore, weeds often carry seed traits such as dormancy and uneven germination, maintaining field populations even under not optimal conditions (Oliveira Júnior, 2011). Among different weed groups, specific characteristics may offer a further competitive capacity to certain species. Nutsedge and slender amaranth have C4 metabolism, which promotes fast growth rates and biomass production due to efficient $\mathrm{CO}_{2}$ assimilation (Brighenti, 2001), while hairy beggarticks can absorb high amounts of soil nutrients, including nitrogen, phosphorus, and micronutrients (Santos \& Cury, 2011). Purple nutsedge's competitive ability is a result of its perennial life cycle and herbaceous size, with reproduction both sexually (aerial and underground seeds) and through vegetative tubers referred to as "nutlets", which facilitate weed dispersion (Ronchi \& Silva, 2004).

Thus, since Barbados gooseberry is a perennial plant with slow initial growth (Madeira et al., 2016), its ability to compete with weeds, especially during initial growth stages, will potentially have a significant impact on yield. As competition with weeds can affect this crop in the initial stages, Madeira et al. (2016) recommend using mulching in the first weeks after transplanting seedlings, to reduce weed emergence in fields. However, additional manual weed picking and mowing are required during the crop cycle.

The objective of this work was to study the interference of purple nutsedge, hairy beggarticks, Benghal dayflower, and slender amaranth on the initial development of Barbados gooseberry.

\section{MATERIAL AND METHODS}

Trials were conducted in a greenhouse, in the city of Alegre, Espírito Santo state, Brazil $\left(21^{\circ} \mathrm{S}\right.$, $42^{\circ} \mathrm{W}$ ), from August 2018 to October 2018. The climate of Southern Espírito Santo is classified, according to Köppen, as type "Aw", with two well-defined seasons during the year, hot and rainy from October to March, and cold and dry from April to September, with $23^{\circ} \mathrm{C}$ average annual temperature, and around 1,200 $\mathrm{mm}$ rainfall (Pezzopane et al., 2012).

The experiment was conducted in a completely randomized design, with five treatments and six replicates. Treatments were composed of Barbados gooseberry in competition with four weed species: slender amaranth (Amaranthus viridis), hairy beggarticks (Bidens pilosa), Benghal dayflower (Commelina benghalensis), purple nutsedge (Cyperus rotundus), and a weed-free control (check).

Weeds were planted in $5 \mathrm{~L}$ plastic pots using rhizomes as propagules for purple nutsedge, stolons for Benghal dayflower, and seeds for both slender amaranth and hairy beggarticks. Four rhizomes were used for purple nutsedge, five-node stolons for Benghal dayflower, and 50 seeds for each hairy beggarticks and slender amaranth. Weeds were thinned 30 days after planting, reducing weed populations to four plants per pot. Right after thinning, weeds were trimmed to a height of $10 \mathrm{~cm}$ from the soil, and Barbados gooseberry was planted in these pots using stems.

Barbados gooseberry was planted directly in the soil using stem cuttings. Stems comprised mature branches collected from the middle canopy of a single healthy and fully developed plant and standardized to $15 \mathrm{~cm}$ length and $0.5 \mathrm{~cm}$ diameter, with five budding nodes, always keeping leaves attached to stems. Stems were planted at $7.5 \mathrm{~cm}$ depth in $5 \mathrm{~L}$ pots where weeds were already grown as before described. Pots were filled with a 2:1 soil:potting mix blend and positioned in $1 \mathrm{~m} \times 1 \mathrm{~m}$ pattern between pots.

The soil mixed with potting mix was classified as Red-Yellow Latosol, medium texture (Santos et al., 2018), collected at $20-30 \mathrm{~cm}$ depth. A soil sample was submitted to chemical analysis, resulting in $\mathrm{pH} 5.46$ in water, $3.57 \mathrm{mg} \mathrm{dm}^{-3}$ of P, $20.00 \mathrm{mg} \mathrm{dm}^{-3}$ of $\mathrm{K}$, $55.00 \mathrm{mg} \mathrm{dm}^{-3} \mathrm{Na}, 0.14 \mathrm{cmolc} \mathrm{dm}^{-3} \mathrm{Ca}$, $0.30 \mathrm{cmolc} \mathrm{dm}^{-3} \mathrm{Mg}, 0.00$ cmolc dm$^{-3}$

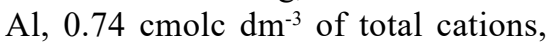
$2.47 \mathrm{cmolc} \mathrm{dm}^{-3}$ of cation exchange capacity at $\mathrm{pH} 7$, and $29.86 \%$ of base saturation. The soil was collected, airdried, and sieved through a $5 \mathrm{~mm}$ mesh. The $\mathrm{pH}$ was corrected by elevating base saturation to $60 \%$ using limestone (90 ENV). Fertilization was based on the recommendation of Madeira et al. (2016) and adapted to pot volume. Pots were watered daily, by adding $15 \mathrm{~mm}$ per pot.

All ratings were performed 90 days after crop planting when plants exhibited uniform growth and development, which shows the beginning of the harvesting stage (Brasil, 2016). To analyze plant vegetative growth and assess the influence of weed competition on leaf size along the stem, the following variables were evaluated: number of leaves (NL); number and length of secondary branches (NSB and LSB) with a minimum length of $5 \mathrm{~cm}$; length and width of proximal leaves (LPL and WPL) $\left(5^{\text {th }}\right.$ leaf at the base of canopy); length and width of medial leaves (LML and WML) (central leaf of middle canopy); and length and width of distal leaves (LDL and WDL) (5 ${ }^{\text {th }}$ leaf in the upper canopy). Chlorophyll a, chlorophyll b, and total chlorophyll were estimated using a digital chlorophyll meter clorofiLOG (CFL 1030 - Falker, Porto Alegre, RS, Brazil), that uses photodiodes for three wavelengths: two detecting red bands close to the peaks of each type of chlorophyll $(\lambda=$ 635 and $660 \mathrm{~nm}$ ), and a third detecting near-infrared $(\lambda=880 \mathrm{~nm})$. Using data from chlorophyll readings, the device estimates a value designated as Falker chlorophyll index (FCI) that is proportional to chlorophyll absorbances (Barbier et al., 2012).

Fresh weight of leaves (FWL) and 
dry weight of leaves (DWL), branches (DWB), and roots (DWR) were assessed for Barbados gooseberry 90 days after planting. For each weed species, dry weight of shoots (DWS) and dry weight of roots (DWR) were also estimated at 90 DAP. To measure dry weight, all fresh samples were dried in a forced-air circulation oven at $65^{\circ} \mathrm{C}$ until reaching constant weight.

Total nitrogen $(\mathrm{TN})$ and crude protein $(\mathrm{CP})$ in leaves were estimated 90 days after planting using the Kjeldahl method, following the procedure described by Galvani \& Gaertner (2006), using protein-nitrogen distiller (TE0363-Tecnal, Piracicaba, SP, Brazil). Crude fiber (CF) was estimated using a commercial fiber analyzer (TE-149 Tecnal, Piracicaba, SP, Brazil) following Van Soest's method (1967). Total ash (TA) was estimated via the calcination of $1 \mathrm{~g}$ digested samples in a muffle oven at $600^{\circ} \mathrm{C}$ for four hours.

The data were submitted to analysis of variance, using the $\mathrm{F}$ test at $5 \%$ probability, and when significant, means were separated using Tukey test at 5\% probability. All statistical analyses were performed using Sisvar 5.0 (Ferreira, 2014).

\section{RESULTS AND DISCUSSION}

Weed competition affected growth and development of Barbados gooseberry during the initial 90 days after planting in greenhouse conditions. Purple nutsedge affected plant growth by reducing the length of secondary branches and number of leaves by $74 \%$ and $85 \%$, respectively, followed by Benghal dayflower, slender amaranth and hairy beggarticks (Table 1). Weed competition with Barbados gooseberry and other crops is due to factors such as competition for space, water, light, and nutrients, and potential negative allelopathic effects (Andrade et al., 2009; Silva \& Silva, 2012). Weeds reduced shoot growth of Barbados gooseberry, where structures used for commercialization, such as leaves, may have reduced development due to decreased nutrient availability, and/or by allelopathic compounds (Albuquerque et al., 2008).

Leaf dimensions of Barbados gooseberry (length and width) were also reduced by weed competition with Benghal dayflower and purple nutsedge (Table 2), leading to the production of leaves under sizes commonly reported, which are from seven to ten centimeters in average length (Brasil, 2016). Variations in leaf dimensions drive leaf size and therefore, are directly correlated with leaf area, which will reflect in the photosynthetic capacity of a plant. Similar results were found by Cabral et al. (2020) where weed competition reduced the leaf area of yacon plants. Therefore, decreases in leaf dimensions of Barbados gooseberry can lead to a reduction in the production of photoassimilates in these plants and, consequently, reduced leaf biomass (González-Sanpedro et al., 2008). In the case of Barbados gooseberry, a reduction in leaf size would also lead to losses in yield, considering that leaves are the plant structure used for consumption and therefore, the focus to increase profitability in this crop.

The elevated competitive capacity of these weed species is derived from their growth biology and the superior capacity to use and compete for resources, leading to elevated absorption of soil nutrients in addition to aggressive characteristics (Pitelli, 1987). Purple nutsedge is quite aggressive due to its fast initial growth and rapid development of vegetative reproductive structures (Nishimoto, 2001). Benghal

dayflower's competitive ability comes from the ability to propagate both vegetatively and via seeds, associated with vigorous and dense growth, covering the soil and limiting the availability of resources to growing crops (Isaac et al., 2007). Due to reduced leaf growth, Barbados gooseberry displayed reduced production of fresh and dry biomass in leaves, branches, and roots, when competing with weeds. Overall, data show reduced production of fresh and dry biomass of leaves and roots compared to weed-free control, regardless of weed species treatments. However, purple nutsedge had a stronger effect on Barbados gooseberry fresh and dry weight of leaves compared to other weed species.

Regarding the potential to produce leaves (fresh), which is the plant part most consumed and therefore has economic importance, data show that competition with weeds leads to decreases of nearly $40 \%$ in Barbados gooseberry production, with the strongest reduction when competing with purple nutsedge (Table 3). These results demonstrate that, in commercial production fields focusing on the production of leaves for fresh consumption, weed competition will significantly compromise the yield of Barbados gooseberry, as it is measured by the production of leaves. These results highlight the importance of implementing weed management practices during the initial development stages of Barbados gooseberry, as well as producing seeds in the greenhouse for

Table 1. Effect of the interference of different weeds on the number of leaves, number, and length of secondary branches of Barbados gooseberry. Alegre, UFES, 2018

\begin{tabular}{lccc}
\hline \multirow{2}{*}{ Weed treatments } & \multicolumn{3}{c}{ Growth variables } \\
\cline { 2 - 4 } & $\mathbf{N}$ & NSB & LSB \\
\cline { 2 - 4 } & \multicolumn{3}{c}{$\mathbf{( c m}^{-1} \mathbf{)}$} \\
\hline Weed-free (control) & $54.66 \mathrm{a}^{*}$ & $2.16 \mathrm{a}$ & $27.08 \mathrm{a}$ \\
A. viridis & $18.83 \mathrm{c}$ & $1.83 \mathrm{a}$ & $17.33 \mathrm{~b}$ \\
B. pilosa & $34.66 \mathrm{~b}$ & $2.00 \mathrm{a}$ & $21.08 \mathrm{~b}$ \\
C. benghalensis & $13.00 \mathrm{~d}$ & $2.15 \mathrm{a}$ & $9.86 \mathrm{c}$ \\
C. rotundus & $8.00 \mathrm{e}$ & $1.66 \mathrm{a}$ & $7.08 \mathrm{c}$ \\
\hline CV $(\%)$ & 22.05 & 31.89 & 21.03 \\
\hline
\end{tabular}

* Means followed by the same letter in the same column do not differ using Tukey's test at $5 \%$ probability. $\mathrm{CV}=$ coefficient of variation. $\mathrm{NL}=$ number of leaves; $\mathrm{NSB}=$ number of secondary branches; LSB= length of secondary branches. 
Table 2. Effect of the interference of different weeds on the length and width of proximal, medial and distal leaves of Barbados gooseberry. Alegre, UFES, 2018.

\begin{tabular}{|c|c|c|c|c|c|c|}
\hline \multirow{3}{*}{ Weed treatments } & \multicolumn{6}{|c|}{ Leaf variables in Barbados gooseberry } \\
\hline & LPL & WPL & LML & WML & LDL & WDL \\
\hline & \multicolumn{6}{|c|}{$\left(\mathrm{cm}^{-1}\right)$} \\
\hline Weed-free (control) & $9.91 \mathrm{a} *$ & $3.66 \mathrm{a}$ & $10.16 \mathrm{a}$ & $3.66 \mathrm{a}$ & $9.00 \mathrm{a}$ & $3.41 \mathrm{a}$ \\
\hline A. viridis & $8.00 \mathrm{ab}$ & $3.58 \mathrm{a}$ & $8.50 \mathrm{a}$ & $3.25 \mathrm{a}$ & $7.16 \mathrm{ab}$ & $2.58 \mathrm{bc}$ \\
\hline B. pilosa & $7.50 \mathrm{ab}$ & $3.75 \mathrm{a}$ & $9.00 \mathrm{a}$ & $4.00 \mathrm{a}$ & $8.00 \mathrm{a}$ & $3.25 \mathrm{a}$ \\
\hline C. benghalensis & $5.83 \mathrm{bc}$ & $2.91 \mathrm{ab}$ & $5.83 b$ & $2.91 \mathrm{bc}$ & $5.83 b$ & $2.91 \mathrm{ab}$ \\
\hline C. rotundus & $5.00 \mathrm{c}$ & $2.08 \mathrm{~b}$ & $5.00 \mathrm{~b}$ & $2.08 \mathrm{c}$ & $5.16 \mathrm{~b}$ & $2.08 \mathrm{c}$ \\
\hline $\mathrm{CV}(\%)$ & 23.00 & 25.26 & 18.21 & 17.91 & 17.06 & 12.57 \\
\hline
\end{tabular}

*Means followed by the same letter in the same column do not differ using Tukey's test at $5 \%$ probability. CV $=$ coefficient of variation. $\mathrm{LPL}=$ length of proximal leaves; $\mathrm{WPL}=$ width of proximal leaves; $\mathrm{LML}=$ length of medial leaves; $\mathrm{WML}=$ width of medial leaves; $\mathrm{LDL}=$ length of distal leaves; WDL $=$ width of distal leaves.

later transplantation to production fields.

The competitive capacity of purple nutsedge is related to its accelerated plant growth, as this species accumulated the highest amount of biomass, both in shoots and roots (26.83 g and $47.16 \mathrm{~g}$ per pot, respectively). Additionally, from tested species, hairy beggarticks caused higher growth reduction to Barbados gooseberry, which may be linked to the growth rate of this weed, as it presented the second largest shoot weight (23.16 $\mathrm{g}$ per pot) (Figure 1). The expressive growth and competitive capacity of hairy beggarticks were also reported by Cabral et al. (2020) competing this weed with yacon plants. The highly competitive capacity of purple nutsedge is due to accelerated initial growth and development, especially of the root system, providing advantages when competing for water and nutrients (Pitelli, 1987). Other weed species had reduced competitive potential (Figure 1) and these results may be linked to mutual competition effects, allowing better development of Barbados gooseberry, as competition is a biological relationship occurring in both directions between crops and weeds. Competitive and fastgrowing crops can suppress the growth of some weed species (Albuquerque et al., 2008).

Data shows that Barbados gooseberry was not significantly affected by Benghal dayflower nor slender amaranth, common weeds affecting horticultural crops, as these weeds displayed lower dry weight of shoots and roots compared to other species in this study (Figure

Table 3. Effect of the interference of different weeds on the dry weight of leaves, branches, and roots and fresh weight of leaves of Barbados gooseberry. Alegre, UFES, 2018.

\begin{tabular}{lllll}
\hline \multirow{2}{*}{ Weed treatments } & \multicolumn{4}{c}{ Fresh and dry weight of Barbados gooseberry } \\
\cline { 2 - 5 } & \multicolumn{1}{c}{ DWL } & DWB & DWR & FWL \\
\cline { 2 - 5 } & \multicolumn{4}{c}{ (g plant $\left.^{-1}\right)$} \\
\hline Weed-free (control) & $2.50 \mathrm{a}^{*}$ & $3.83 \mathrm{ab}$ & $2.16 \mathrm{a}$ & $4.64 \mathrm{a}$ \\
A. viridis & $0.42 \mathrm{bc}$ & $4.66 \mathrm{a}$ & $0.24 \mathrm{~b}$ & $0.79 \mathrm{bc}$ \\
B. pilosa & $0.76 \mathrm{~b}$ & $3.50 \mathrm{ab}$ & $0.19 \mathrm{~b}$ & $1.41 \mathrm{~b}$ \\
C. benghalensis & $0.44 \mathrm{bc}$ & $3.33 \mathrm{c}$ & $0.16 \mathrm{~b}$ & $0.82 \mathrm{bc}$ \\
C. rotundus & $0.23 \mathrm{c}$ & $4.33 \mathrm{ab}$ & $0.14 \mathrm{~b}$ & $0.43 \mathrm{c}$ \\
\hline CV (\%) & 33.69 & 19.25 & 32.28 & 28.13 \\
\hline
\end{tabular}

* Means followed by the same letter in the same column do not differ using Tukey's test at $5 \%$ probability. $\mathrm{CV}=$ coefficient of variation. $\mathrm{DWL}=$ dry weight of leaves; $\mathrm{DWB}=$ dry weight of branches; DWR= dry weight of roots; FWL= Fresh weight of leaves.

1). These results indicate these weeds have a reduced ability to interfere with Barbados gooseberry growth, information relevant to growers, and extension programs when selecting weed management practices for this crop.

In addition to growth and morphological variables, weed competition affected the photosynthetic capacity of Barbados gooseberry as well, by decreasing chlorophylls a, b, and total chlorophyll in leaves (Table 4). Weed competition for resources such as water and nutrients, especially nitrogen (Argenta et al., 2001), diminishes the initial establishment of Barbados gooseberry. Based on bromatological analyzes, concentrations of total nitrogen and crude fiber in leaves of Barbados gooseberry were not significantly affected by weed interference. However, crude protein concentrations were decreased by competition with purple nutsedge, Benghal dayflower, and hairy beggarticks, resulting in reductions of $23 \%, 15 \%$, and $10 \%$ in the protein content, respectively (Table 4), lower than average values observed in the literature (Takeiti et al., 2009). The competition for nutrients by weeds species may be linked to their adapted roots system. In fact, Benghal dayflower has a root system with a large number of roots that allow increased nutrient absorption surface of the soil (Martins et al., 2007). Thus, weed competition compromises leaf nutrient accumulation and consequently Barbados gooseberry' nutritional quality, which is mainly characterized by being a protein-rich food. 
Table 4. Effect of the interference of different weeds on the chlorophyll a, b, total chlorophyll, total nitrogen, crude protein, crude fiber, and total ash in Barbados gooseberry. Alegre, UFES; IFES, 2018.

\begin{tabular}{|c|c|c|c|c|c|c|c|}
\hline \multirow{3}{*}{ Weed treatments } & \multicolumn{7}{|c|}{ Foliar concentrations in Barbados gooseberry } \\
\hline & \multirow{2}{*}{ CA } & \multirow{2}{*}{$\mathbf{C B}$} & \multirow{2}{*}{ TC } & TN & $\mathbf{C P}$ & $\mathbf{C F}$ & TA \\
\hline & & & & \multicolumn{4}{|c|}{$\left(\mathrm{g} \mathrm{kg}^{-1}\right)$} \\
\hline Weed-free (control) & $28.5 \mathrm{a}^{*}$ & $7.5 \mathrm{a}$ & $35.9 \mathrm{a}$ & $22.7 \mathrm{a}$ & $141.8 \mathrm{ab}$ & $80.5 \mathrm{a}$ & $6.1 \mathrm{~d}$ \\
\hline A. viridis & $23.1 \mathrm{e}$ & $4.7 \mathrm{~d}$ & $28.0 \mathrm{~d}$ & $24.6 \mathrm{a}$ & $154.1 \mathrm{a}$ & $75.6 \mathrm{a}$ & $9.6 \mathrm{ab}$ \\
\hline B. pilosa & $27.3 \mathrm{ab}$ & $6.5 b$ & $34.0 \mathrm{~b}$ & $19.3 \mathrm{a}$ & $121.0 \mathrm{~cd}$ & $81.1 \mathrm{a}$ & $7.4 \mathrm{bc}$ \\
\hline C. benghalensis & $25.8 \mathrm{~d}$ & $5.5 \mathrm{c}$ & $31.5 \mathrm{c}$ & $20.3 \mathrm{a}$ & $127.3 \mathrm{bc}$ & $79.6 \mathrm{a}$ & $10.6 \mathrm{a}$ \\
\hline C. rotundus & $27.0 \mathrm{bc}$ & $6.0 \mathrm{bc}$ & $33.1 \mathrm{bc}$ & $19.5 \mathrm{a}$ & $109.4 \mathrm{~d}$ & $84.9 \mathrm{a}$ & $10.7 \mathrm{a}$ \\
\hline CV (\%) & 9.60 & 17.18 & 9.89 & 10.35 & 8.39 & 8.52 & 16.09 \\
\hline
\end{tabular}

*Means followed by the same letter in the same column do not differ using Tukey's test at $5 \%$ probability. CV= coefficient of variation. $\mathrm{CA}=$ chlorophyll $\mathrm{a} ; \mathrm{CB}=$ chlorophyll $\mathrm{b} ; \mathrm{TC}=$ total chlorophyll; $\mathrm{TN}=$ total nitrogen; $\mathrm{CP}=$ crude protein; $\mathrm{CF}=$ crude fiber; $\mathrm{TA}=$ total ash .

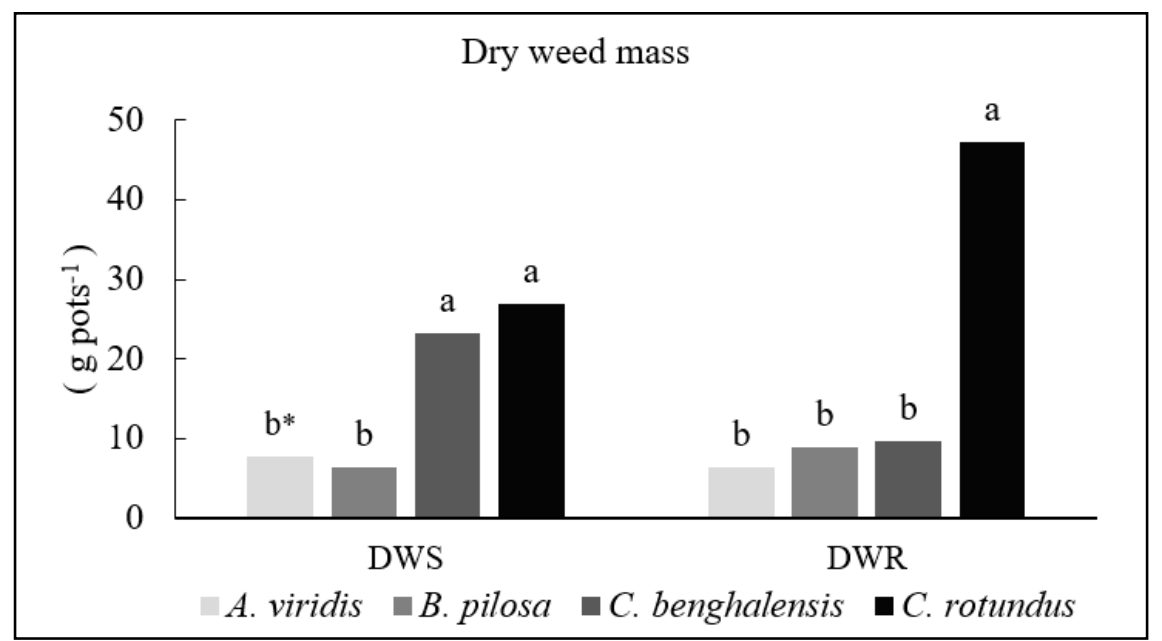

Figure 1. Dry weight of shoots (DWS) and roots (DWR) of weed species 90 days after Barbados gooseberry planting. *Means followed by the same letter in the bars do not differ using Tukey's test at 5\% probability. Alegre, UFES, 2018.

In contrast, purple nutsedge and hairy beggarticks led to an increase in total inorganic materials (ash), also described as a mineral residue (sodium, potassium, magnesium, calcium, iron, phosphorus, and other mineral compounds). Therefore, higher concentrations of total ash observed in Barbados gooseberry under influence of weeds (Table 4), could be a result of changes in plant adaptive metabolism in competitive environments, allowing boosted crop absorption and accumulation of minerals (Queiroz et al., 2015b).

Among weeds evaluated in this study, purple nutsedge and hairy beggarticks affected Barbados gooseberry growth and development the most. Therefore, adopting management practices to techniques potentially affecting these results.

\section{ACKNOWLEDGMENTS}

This work was supported by the Espírito Santo Research and Innovation Support Foundation (FAPES) and National Council for Scientific and Technological Development (CNPq) via scholarships and financial support. Bromatological analyses were performed by the Federal Institute of Science and Technology (IFES, Alegre Campus).

\section{REFERENCES}

effectively control these weeds are recommended and should be adopted when establishing production systems. These weeds, when not properly managed, can become a limiting factor in the development of Barbados gooseberry, especially during the growth and initial establishment of the crop, when plants are less competitive and more susceptible to weed pressure (Pitelli, 1987; Silva \& Silva, 2012).

Barbados gooseberry initial growth and development in a greenhouse condition, as well as its crude protein content, was reduced due to weed interference, remarkably by purple nutsedge. Additional work must be conducted evaluating these findings under field conditions, using different seedling production and planting
ALBUQUERQUE, JAA; SEDIYAMA, T; SILVA, AA; CARNEIRO, JES; CECON, PR; ALVES, JMA. 2008. Interferência de plantas daninhas sobre a produtividade da mandioca (Manihot esculenta). Planta daninha 26: 279-289.

ANDRADE, HM; BITTENCOURT, AHC; VESTENA, S. 2009. Potencial alelopático de Cyperus rotundus L. sobre espécies cultivadas. Ciência Agroecológica 33: 1984-1990.

ARGENTA, G; SILVA, PRF; BORTOLINI, CG; FORSTHOFER, EL; STRIEDER, ML. 2001. Relação da leitura do clorofilômetro com os teores de clorofila extraível e de nitrogênio na folha de milho. Revista Brasileira Fisiologia Vegetal 13: 158-167.

BARBIER, JE; ROSSIELLO, ROP; SILVA, RVMM; RIBEIRO, RC; MORENZ, MJF. 2012. Um novo clorofilômetro para estimar os teores de clorofila em folhas do capim Tifton 85. Ciência Rural 42: 2242-2245.

BRASIL. 2016. Espécies nativas da flora brasileira de valor econômico atual ou potencial: Plantas para o futuro: Região 
Centro-Oeste. Brasília, BR: Secretaria de Biodiversidade. 1160p.

BRIGHENTI, AM. 2001. Biologia de plantas daninhas. In: OLIVEIRA JÚNIOR, RS; CONSTANTIN, J (eds). Plantas daninhas e seu manejo. Guaíba: Agropecuária 18-58p.

CABRAL, MO; OLIVEIRA, FL; DALVI, LP; TEIXEIRA, AG; ROCHA, LJFN; PEDROSA, JLF. 2020. Influence of weeds on yacon initial growth and development. Planta daninha 38: 2-6.

DEMÉTRIO, CS; FORNASIERI FILHO, D; CAZETTA, JO; CAZETTA, DA. 2008. Desempenho de híbridos de milho submetidos a diferentes espaçamentos e densidades populacionais. Pesquisa Agropecuária Brasileira 43: 1691-1697.

FERREIRA, DF. 2014. Sisvar: a guide for its bootstrap procedures in multiple comparisons. Ciência Agrotecnológica 38: 109-112.

GALON, L; FERREIRA, EA; CONCENÇO, G; SILVA, AA; SILVA, DV; SILVA, AF; ASPIAZÚ, I; VARGAS, L. 2013. Características fisiológicas de biótipos de Conyza bonariensis resistentes ao glyphosate cultivados sob competição. Planta Daninha 31: 859- 866.

GALVANI, F; GAERTNER, E. 2006. Adequação da metodologia Kjeldahl para determinação de nitrogênio total e proteína bruta. Embrapa Pantanal (Circular Técnico 63: 1-8).

GARCIA, JA; CORRÊA, RC; BARROS, L; PEREIRA, C; ABREU, RM; ALVES, MJ; FERREIRA, IC. 2019. Phytochemical profile and biological activities of 'Ora-pronóbis' leaves (Pereskia aculeata Miller), an underexploited superfood from the Brazilian Atlantic Forest. Food Chemistry 294: 302-308.

GONZÁLEZ-SANPEDRO, MC; LE TOAN, T; MORENO, J; KERGOAT, L; RUBIO, E. 2008. Seasonal variations of leaf area index of agricultural fields retrieved from Landsat data. Remote Sensing of Environment 112: 810-824.

ISAAC, WAP; BRATHWAITE, RA; COHEN, JE; BEKELE, I. 2007. Effects of alternative weed management strategies on Commelina diffusa Burm. Infestations in fairtrade banana (Musa spp.) in St. Vincent and the Grenadines. Crop Protection 26: 1219-1225.

MADEIRA, NR; AMARO, GB; MELO, RDC; BOTREL, N; ROCHINSKI, E. 2016. Cultivo de ora-pro-nóbis (Pereskia aculeata) em plantio adensado sob manejo de colheitas sucessivas. Embrapa Hortaliças (Circular Técnico 156: 2-20).

MARTINS, MC; CÂMARA, GMS; PEIXOTO, CP; MARCHIORI, LFS; LEONARDO, V; MATTIAZZI, P. 2007. Épocas de semeadura, densidades de plantas e desempenho vegetativo de cultivares de soja. Science Agriculture. 5: 851-8.

NISHIMOTO, RK. 2001. Purple nutsedge tuber sprouting. Weed Biology \& Management 1: 203-208.

OLIVEIRA JUNIOR, RS. 2011. Biologia e manejo de plantas daninhas. 1. ed. Curitiba: Omnipax. 362p.

PEZZOPANE, JEM; CASTRO, FS; PEZZOPANE, JRM; CECÍLIO, RA. 2012. Agrometeorologia: aplicações para o Espírito Santo. Alegre: UFES. $174 \mathrm{p}$.

PINTO, NDC; DUQUE, APDN; PACHECO, NR; MENDES, RF; MOTTA, EVDS; BELLOZI, PMQ; SCIO, E. 2015. Pereskia aculeata: a plant food with antinociceptive activity. Pharmaceutical Biology 53: 1780-1785.

PITELLI, RA. 1987. Competição e controle das plantas daninhas em áreas agrícolas. Série técnica IPEF 4: 1-24.

QUEIROZ, CRAA; FERREIRA, LPGLB; MELO, CMT; ANDRADE, RR. 2015a. Ora-pro- nóbis em uso alimentar humano: percepção sensorial. Revista Verde de Agroecologia e Desenvolvimento Sustentável 10: 1-5.

QUEIROZ, CRAA; SANTOS MORAES, CM; ANDRADE, RR; PAVANI, LC. 2015 b. Crescimento inicial e composição química de Pereskia aculeata Miller cultivada em diferentes luminosidades. Revista Agrogeoambiental 7: 93-104.

RONCHI, CP; SILVA, AA. 2004. Weed control in young coffee plantations through postemergence herbicide application on total area. Planta Daninha 22: 607-615.

SANTOS, HG; JACOMINE, PKT; ANJOS, LHC; OLIVEIRA, VA; LUMBRERAS, JF; COELHO, MR; CUNHA, TJF. 2018. Sistema brasileiro de classificação de solos. Brasília, BR: Embrapa. 356p.

SANTOS, JB; CURY, JP. 2011, Picão-preto: uma planta daninha especial em solos tropicais. Planta Daninha 29:1159-1172.

SILVA, AFA; SILVA, L. 2012. Interferência de plantas daninhas sobre plantas cultivadas. Agropecuária Científica no Semiárido 8: 1-6.

SOUZA, LF; CAPUTO, L; BARROS, I; BERGMAN, I; FRATIANNI, F; NAZZARO, F; FEO, V. 2016. Pereskia aculeata Muller (cactaceae) leaves: chemical composition and biological activities. International Journal of Molecular Sciences 17: 1478p.

TAKEITI, CY; ANTONIO, GC; MOTTA, EM; COLLARES-QUEIROZ, FP; PARK, KJ. 2009. Nutritive evaluation of non-conventional leafy vegetable (Pereskia aculeata Miller). International Journal of Food Sciences and Nutrition 60: 148-160p.

VAN SOEST, PJ. 1967. Use of detergents in the analysis of fibrous feeds. Determination of plant cell wall constituents. Journal of Association of Official Analytical Chemists 46: 829-835p. 